\title{
Performance Optimization of Dual Pressure Heat Recovery Steam Generator (HRSG) in the Tropical Rainforest
}

\author{
Sidum Adumene', Barinaadaa Thaddeus Lebele-Alawa ${ }^{2}$ \\ ${ }^{1}$ Department of Marine Engineering, Rivers State University of Science and Technology, Port Harcourt, Nigeria \\ ${ }^{2}$ Department of Mechanical Engineering, Rivers State University of Science and Technology, Port Harcourt, \\ Nigeria \\ Email: sidum.adumene@ust.edu.ng, lebele-alawa.thaddeus@ust.edu.ng
}

Received 23 May 2015; accepted 26 June 2015; published 30 June 2015

Copyright (C) 2015 by authors and Scientific Research Publishing Inc.

This work is licensed under the Creative Commons Attribution International License (CC BY).

http://creativecommons.org/licenses/by/4.0/

(c) (i) Open Access

\section{Abstract}

This work evaluates the performance optimization of heat recovery steam generator system in Afam VI power plant, Rivers State. Nigeria. Steady state monitoring and direct collection of data from the plant was performed including logged data for a period of 12 months. The data were analysed using various energy equations. Hysys software was used to model the temperature across the heating surfaces, and MATLAB software was used to determine the heat transfer coefficient, heat duties, steam flow, effectiveness of the HRSG. The optimization technique was carried out by varying the exhaust gas flow, exhaust gas temperature, steam pressure and the theoretical introduction of duct burner for supplementary firing. The results show that between $490^{\circ} \mathrm{C}$ and $526^{\circ} \mathrm{C}$, the percentage increase in the overall heat absorbed in the HRSG is $37.39 \%$. It also show that for an increase in the exhaust gas mass flow by $80 \mathrm{~kg} / \mathrm{s}$, the steam generation increase by $19.29 \%$ and $18.18 \%$ for the low and high pressure levels respectively. The overall result indicates an improvement in the HRSG energy efficiency and steam generation. As the exhaust gas mass flow and temperature increases, the steam generation and system effectiveness greatly improved under the various considerations, which satisfy the research objective.

\section{Keywords}

HRSG, Effectiveness, Exhaust Gas Flow, Exhaust Gas Temperature, Steam Flow, Heat Duty

\section{Introduction}

Heat Recovery Steam Generator is the standard term used for a steam generator producing steam by cooling hot

How to cite this paper: Adumene, S. and Lebele-Alawa, B.T. (2015) Performance Optimization of Dual Pressure Heat Recovery Steam Generator (HRSG) in the Tropical Rainforest. Engineering, 7, 347-364.

http://dx.doi.org/10.4236/eng.2015.76031 
gases. Heat recovery system is obviously a very desirable energy source, since the product is available almost operating cost-free and increases the efficiency of the cycle in which it is placed, either for steam generation or for incremental power generation. Heat recovery steam generator can regain energy from waste-gas streams, such as incinerator gases, furnace effluents or most commonly the exhaust of a gas turbine.

In modern operation of heat transfer equipment such as heat recovery steam generator (HRSG), the exit gas temperature determines the amount of energy extracted from the flue gas stream of the gas turbine. This is an indication of the HRSG performance. Therefore, efforts are often made to lower the stack temperature as much as possible taken into consideration cost effectiveness and low temperature corrosion. The modifications of a single pressure HRSG to multi-pressures have also improve the energy efficiency of the heat recovery steam generator unit [1]. Heat recovery steam generators can be made up from a number of components, including evaporators, economizers, superheaters, reheater, integral deaerators and preheaters. Each of the heat transfer sections performs a specific task, and the one that is selected are generally dictated by the required steam conditions for process use or power generation, the type of power generation and/or the efficiency requirement, weighed against HRSG costs.

Heat recovery steam generator evaporator sections act to vaporize water and produce steam in one component. A bank of finned tubes is extended through the gas turbine's exhaust gas path from a steam drum (top) to a lower (mud) drum. The gas turbine is a very satisfactory means of producing mechanical power [2] [3]. Feed water is carefully supplied at the appropriate pressure to the upper drum below the water level, and circulates from the upper to lower drum, back to the upper drum by convection within the finned tube.

The economizers are serpentine finned-tube gas-to water heat exchangers, and add sensible heat (preheat) to the feed water, prior to its entry into the steam drum of the evaporator. Different heat transfer applications require different types of hardware and different configurations of heat transfer equipment [4]. In single pressure HRSG, the economizer will be located directly downstream (with respect to gas flow) of the evaporator section. In multi-pressure unit, the various economizer sections may be split, and be located in several locations both upstream and downstream of the evaporators. The superheater is a separate serpentine tube heat exchanger which is located upstream (with respect to gas flow) of the associated evaporator. This component adds sensible heat to the dry steam, superheating it beyond the saturation temperature.

In gas turbine heat recovery steam generator, its performance is dependent on the gas turbine exit temperature, inlet gas temperature, feed water temperature and steam pressure. The low exhaust gas temperature generates less steam on unit gas mass basis in the HRSG evaporator unit [5].

The HRSG is widely used equipment in various industries to which include process, power generation, and petroleum industry. The development of HRSG as a component part of the combined power cycle and cogeneration has improved power production and enhanced costs effectiveness within the sector. Energy and materials saving consideration, as well as economical consideration have stimulated the high demand for high efficient HRSG.

Meeting the growing requirement for cost-effective and undisturbed operation in today's economical environment drives power plants to reach for the best possible performance and higher availability. Power plants can no longer afford to operate without knowing the exact HRSG performances at all times or without taking immediate actions when problems occur. Even minor decreases in the HRSG efficiency and performance can cause significant financial and energy losses during the production phase of the plant. This called for several optimization techniques to maintain energy efficiency of the HRSG.

The hierarchical strategy implied for optimization of the whole combine-cycle power plant is as follows optimization of the gas turbine cycle, optimization of the operation parameters of the HRSG, and detailed optimization of the single heat exchanger section in the HRSG. One of the suggested ways to reach theoretically maximum efficiency is by increasing the turbine inlet temperature [6]. This requires a highly advanced cooling system to cool down the blades of the gas turbine. With existing technology levels, focus can be fixed on the HRSG, and its operating parameters to improve the efficiency of the combined-cycle plants. Optimization of the operating parameters of HRSG is the first step in the optimum design of the plants as stated in Franco and Russo [7].

Reddy et al. [8] suggested a second law analysis of the heat recovery steam generator. This method is basically used to optimize and design various thermal units by minimizing the entropy generation in the unit. The operating parameters are non-dimensionalized, and an equation for the entropy generation number helps to study the effect of the dimensionless operating parameter.

Casarosa et al. [1] applied thermodynamic optimization technique which considered only the irreversibility 
due to temperature difference between hot and cold streams. Although this method did not apply any constraint on the cost of the HRSG, and on the surface area, it still gives a rough idea about the selection of operating parameters for the HRSG.

Ongiro et al. [6] developed mathematical models to simulate and study the performance of the HRSG. Subhramanyam et al. [9] considered the computational complexity of the HRSG and how it could be model. The proposed method calculates the velocity and temperature fields by discretisation and the solution of conservation equation derived for a HRSG of particular geometry and duty.

Dumont and Heyen [10] suggested a mathematical model for modeling and designing a once-through heat recovery steam generator. In a conventional boiler, each tube plays a well defined role like water preheating, vaporization and superheating. Empirical equations are readily available to predict the average heat transfer in each region which is not the case in a once through boiler. This increases the mathematical complexity as well as the number of equations to be solved for modeling these boilers.

The even increasing technology is the field of HRSG, as a potential option to improve the efficiency of the system. This necessitates having a numerical flow model with the capability to simulate combustion and the flow in the HRSG model, as well as the flexibility to simulate those for different designs with acceptable accuracy.

Valdes et al. [11] performed a thermo economic optimization of combined cycle gas turbine power plants using a genetic algorithm. They proposed two different objective functions; aimed at minimizing the cost of production per unit electricity and maximizing the annual cash flow.

Mohammad et al. [12] performed an exergetic and economic evaluation of the effect of HRSG configurations on the performance of combined cycle power plants. Their result showed that an increase in the number of pressure levels affects the exergy destruction rate in the HRSG.

Attala et al. [13] optimize a dual pressure level combined cycle gas turbine. They worked with a simulation program that included three models; the first simulates the cycle, the second evaluates the thermodynamic and thermo-economic parameters and the third is the optimization model.

Subrahmanyam et al. [9] discussed about the various factors affecting the HRSG design for achieving the highest combined cycle efficiency with cheaper, economical and competitive designs and with the highest requirement to meet the shorter deliveries.

Casarosa et al. [1] determine the operating parameters using both thermodynamic and thermo-economic function by analytical and numerical (mathematical) methods.

Reddy et al. [8] applied second law analysis for a waste heat recovery steam generator which consists of an economizer, an evaporator and a superheater. Introducing multiple pressure steam generation in the HRSG of a combined power plant improves the performance of the plant than that of a corresponding single pressure system

Bassily [14] modeled a dual and triple pressure reheat combined cycle with a preset for pinch points, the temperature difference for superheat approach, the steam turbine inlet temperature at steam turbine and the outlet without a dearator in steam bottoming cycle. Srinvivas [15] suggested an improved location for a deaerator in a triple pressure HRSG.

Mohagheghi and Shayegan [16] developed computer code to examine the competence for a variety of types of HRSG, from the thermodynamic optimization of the HRSG, they obtained a high rate of generating power in the steam cycle. Zhixin et al. [17] designed a condition of a single pressure waste heat recovery system when the temperature or flow rate of exhaust gas fluctuates; the results show that systems designed at the upper boundary of fluctuation range of exhaust gas could generate more power.

Manassaldi et al. [18] proposed a methodology which applied a mixed non linear program model to obtain the design according to their criteria; Net power maximization, the ratio between net power and material weight maximization, and the net heat transfer maximization.

Alus and Petrovic [19] performed an optimization of a triple pressure combined cycle gas turbine (CCGT). The objective of the optimization was to minimize the production cost of electricity in the CCGT power plant based on energetic and economic analysis. Ghazl et al. [20] carried out an optimization study to find the best design parameters (high and low degree pressures, steam mass flow rates, pinch point temperature difference and the duct burner fuel consumption flow rate) of a dual pressure combined cycle power. Total cost per unit of produced steam energy is defined as the objective function.

Vytla [21] performed a CFD modeling of the HRSG and its components using fluent. He focused on how 
CFD analysis can be used to assess the impact of the gas-side flow on the HRSG performance and identify design modification to improve the performance

In this work a sensitivity analysis and parametric modulation were carried out and the modeling of the HRSG using a computer program was created to produce the equation that can predict the functionality and optimization of the HRSG.

The study area is the Niger Delta area of Nigeria which lies between latitudes $4^{\circ} \mathrm{N}$ and $6^{\circ} \mathrm{N}$, and longitude $5^{\circ} \mathrm{E}$ and $8^{\circ} \mathrm{E}$. The vegetation of the area is equatorial rain forest. There are basically two seasons-the wet (April to September) and the dry (October to March). However, rain fall throughout the year. The mean annual rainfall in the area is between $200 \mathrm{~mm}$ in the North and $400 \mathrm{~mm}$ in the South of the region. The mean daily temperature of the region varies slightly from $27^{\circ} \mathrm{C}$ to $30^{\circ} \mathrm{C}$ all the year round. The maximum and minimum temperatures are $40^{\circ} \mathrm{C}$ and $20^{\circ} \mathrm{C}$ respectively. The relative humidity varies between a minimum of $70 \%$ and a maximum of $90 \%$ [22] [23].

\section{Material and Methods}

Data collected from the Afam VI HRSG was done by direct observation from the monitoring screen of the automated system called human machine interface (HMI), including data from log books and manufacturers manual as shown in Table 1 and Table 2. Such parameters include temperature of the flue gas, feed water pressure, mass flow rate, and ambient operating condition of the gas turbine. The Data obtained for this analysis are from the Afam VI power plant, Port Harcourt, Rivers State Nigeria. The design specification of the gas turbine and the dual heat recovery steam generator is shown below.

\section{Technical Data of the Gas Turbine}

Model:

Power output (gross)

Compressor pressure ratio

Mass flow rates (kg/s)

Efficiency (LHV), \%

Heat Rate (kJ/kWh)

Isentropic Efficiency \%

Natural Gas (LHV)

Combustor/burner Type

Nox (at $15 \% \mathrm{O}_{2}$, dy), ppmv

Technical Data of the HRSG

MCR (LP)

S. H Steam Pressure

S. H Steam Temperature

MCR (HP)

S. H Steam Pressure

S. H Steam Temperature

To predict the optimum performance of the HRSG, energy conservation principle is employed, hence the use of energy models to analyze the operating parameter of the HRSG is made. The total heat transfer may be related with its governing (operating) parameter. Hysys was used in simulating the temperature drop across the heating element in the HRSG, and MATLAB software was used to analysed the performance for optimization.

\subsection{Heat Transfer Coefficients and Effectiveness Calculation Model}

This method is based on heat transfer coefficients to obtain the heat transfer area for each heat exchanger in high and low pressure level of the dual pressure HRSG. The effectiveness of the heating surfaces in the HRSG is also calculated with Equations (3), (4).

The overall heat transfer coefficient $\mathrm{U}$ by the total heat exchange area is calculated as follows (Ahmadi et al., [24]):

$$
U A_{T}=\frac{Q}{(f \cdot L M T D)} ; A_{T}=A_{\text {hrsg }}=\sum_{S H} A_{S H}+\sum_{E V A} A_{E V A}+\sum_{E C} A_{E C}
$$


Table 1. Average operating parameters of the HRSG.

\begin{tabular}{|c|c|c|c|c|c|c|c|c|c|c|c|}
\hline \multicolumn{6}{|c|}{ LP Section } & \multicolumn{6}{|c|}{ HP Section } \\
\hline Time & $\begin{array}{c}\text { FW Pres. } \\
\text { Bar }\end{array}$ & $\begin{array}{c}\text { FW Flow, } \\
\mathrm{kg} / \mathrm{s}\end{array}$ & $\begin{array}{c}\text { Stm Pres. } \\
\text { Bar }\end{array}$ & $\begin{array}{c}\text { Stm Flow } \\
\mathrm{kg} / \mathrm{s}\end{array}$ & $\begin{array}{c}\text { Stm } \\
\text { Temp, }{ }^{\circ} \mathrm{C}\end{array}$ & $\begin{array}{c}\text { FW Pres. } \\
\text { Bar }\end{array}$ & $\begin{array}{c}\text { FW Flow, } \\
\mathrm{kg} / \mathrm{s}\end{array}$ & $\begin{array}{c}\text { Stm Pres. } \\
\text { Bar }\end{array}$ & $\begin{array}{c}\text { Stm flow, } \\
\mathrm{kg} / \mathrm{s}\end{array}$ & $\begin{array}{c}\text { Stm } \\
\text { Temp, }{ }^{\circ} \mathrm{C}\end{array}$ & $\begin{array}{c}\text { Stack } \\
\text { Temp, }{ }^{\circ} \mathrm{C}\end{array}$ \\
\hline 0:00 & 11 & 57 & 4.6 & 56 & 256 & 128 & 191 & 86 & 189 & 506 & 106 \\
\hline $2: 00$ & 12 & 57 & 4.6 & 56 & 256 & 130 & 190 & 86 & 189 & 504 & 104 \\
\hline 4:00 & 11 & 58 & 4.6 & 55 & 256 & 126 & 191 & 86 & 189 & 505 & 107 \\
\hline $6: 00$ & 12 & 56 & 4.6 & 56 & 256 & 124 & 192 & 86 & 189 & 504 & 107 \\
\hline 8:00 & 11 & 57 & 4.6 & 55 & 256 & 128 & 185 & 86 & 189 & 516 & 106 \\
\hline $10: 00$ & 12 & 57 & 4.8 & 56 & 256 & 127 & 189 & 86 & 189 & 502 & 109 \\
\hline $12: 00$ & 10 & 57 & 4.6 & 57 & 256 & 125 & 188 & 86 & 189 & 501 & 101 \\
\hline $14: 00$ & 11 & 58 & 4.6 & 57 & 256 & 126 & 192 & 86 & 190 & 509 & 112 \\
\hline $16: 00$ & 11 & 58 & 4.6 & 57 & 256 & 127 & 193 & 86 & 190 & 508 & 112 \\
\hline 18:00 & 11 & 59 & 4.6 & 57 & 256 & 126 & 192 & 86 & 190 & 505 & 111 \\
\hline 20:00 & 11 & 59 & 4.7 & 57 & 256 & 125 & 192 & 86 & 190 & 504 & 112 \\
\hline $22: 00$ & 11 & 57 & 4.6 & 57 & 256 & 126 & 192 & 86 & 190 & 505 & 112 \\
\hline
\end{tabular}

Table 2. Average operating parameters of the gas turbine.

\begin{tabular}{cccccccccc}
\hline Time & $\begin{array}{c}\text { Amb. } \\
\text { Temp, }{ }^{\circ} \mathrm{C}\end{array}$ & $\begin{array}{c}\text { Pres. Ratio, } \\
\text { Bar }\end{array}$ & $\begin{array}{c}\text { Amb } \\
\text { Hum. } \%\end{array}$ & $\begin{array}{c}\text { Fuel gas } \\
\text { flow, kg/s }\end{array}$ & $\begin{array}{c}\text { Air mass } \\
\text { flow, kg/s }\end{array}$ & $\begin{array}{c}\text { Power } \\
\text { factor }\end{array}$ & $\begin{array}{c}\text { Exhaust } \\
\text { Temp, }{ }^{\circ} \mathrm{C}\end{array}$ & $\begin{array}{c}\text { Exh. Mass } \\
\text { flow, kg/s }\end{array}$ & $\begin{array}{c}\text { Power } \\
\text { output, MW }\end{array}$ \\
\hline 0:00 & 26.7 & 12.3 & 65 & 7.9 & 437.1 & 0.97 & 526 & 445 & 133 \\
$2: 00$ & 27.8 & 12.3 & 66 & 7.9 & 432.1 & 0.95 & 528 & 440 & 133 \\
$4: 00$ & 27.5 & 12.4 & 58 & 7.9 & 432.1 & 0.96 & 528 & 440 & 133 \\
$6: 00$ & 27.3 & 12.3 & 59 & 7.8 & 430.2 & 0.97 & 529 & 438 & 131 \\
$8: 00$ & 27.1 & 12.3 & 53 & 7.8 & 437.2 & 0.96 & 529 & 445 & 131 \\
$10: 00$ & 29.3 & 11.9 & 61 & 7.8 & 424.2 & 0.94 & 528 & 432 & 132 \\
$12: 00$ & 31.9 & 11.5 & 47 & 7.9 & 422.1 & 0.95 & 526 & 430 & 132 \\
$14: 00$ & 33.5 & 10.1 & 38 & 7.9 & 420.1 & 0.96 & 523 & 428 & 130 \\
$16: 00$ & 32.4 & 11.4 & 52 & 7.9 & 422.1 & 0.96 & 523 & 430 & 132 \\
$18: 00$ & 30.6 & 11.9 & 59 & 7.9 & 427.1 & 0.95 & 525 & 435 & 133 \\
20:00 & 28.9 & 12.1 & 65 & 7.9 & 432.1 & 0.96 & 525 & 440 & 133 \\
\hline
\end{tabular}

The logarithmic mean temperature difference is estimated from the following equation;

$$
L M T D=\left[\frac{\left(T_{g i}-T_{w e}\right)-\left(T_{g e}-T_{w i}\right)}{\ln \left(\frac{T_{g i}-T_{w e}}{T_{g e}-T_{w i}}\right)}\right]
$$




$$
\begin{aligned}
\varepsilon_{H R S G_{L P \text { components }}}= & \frac{\text { Actual heat transfer rates }}{\text { Max. possible heat transfer rate }}=\frac{Q}{Q_{\max }} \\
& =\frac{m_{s}\left(h_{\text {out }}-h_{\text {in }}\right) L P}{m_{g} C_{p g}\left(T_{\text {gin }}-T_{\text {gout }}\right)}=\frac{m_{s} C_{p w}\left(T_{\text {wout }}-T_{\text {win }}\right) L P}{m_{g} C_{p g}\left(T_{\text {gin }}-T_{\text {gout }}\right)} \\
\varepsilon_{H R S G_{H P \text { components }}} & =\frac{\text { Actual heat transfer rates }}{\text { Max. possible heat transfer rate }}=\frac{Q}{Q_{\text {max }}} \\
& =\frac{m_{s}\left(h_{\text {out }}-h_{\text {in }}\right) H P}{m_{g} C_{p g}\left(T_{\text {gin }}-T_{\text {gout }}\right)}=\frac{m_{s} C_{p w}\left(T_{\text {wout }}-T_{\text {win }}\right) H P}{m_{g} C_{p g}\left(T_{\text {gin }}-T_{\text {gout }}\right)}
\end{aligned}
$$

\subsection{Heat Duty Calculation Model}

The first step to simulate the HRSG performance is to balance the mass and energy transfer between the hot and cold streams (gas side and water/steam side) on different heat exchanger when the designed parameters (the flow rate, temperature, pressure of superheated steam and outlet temp of the exhaust gases, the heat duty) can be obtained (Ahmadi P. and Dincer I. [25]). The heat duty of the HRSG elements and the exhaust gas were modeled using the below energy equations.

Energy balance can be expressed as follows;

$$
\begin{gathered}
Q_{T}=\left[Q_{S H}+Q_{E V A}+Q_{E C}\right]_{H P}+\left[Q_{S H}+Q_{E V A}+Q_{E C}\right]_{L P} \\
\left(Q_{S H}\right)_{H P}=Q_{S H 1_{H P}}+Q_{S H 2_{H P}}+Q_{S H 3_{H P}} \\
Q_{S H 1_{H P}}=m_{s}=m_{g} C_{p g}\left(T_{g 1}-T_{g 2}\right) \\
Q_{S H 2_{H P}}=m_{s}\left(h_{15}-h_{14}\right)_{H P}=m_{g} C_{p g}\left(T_{g 2}-T_{g 3}\right) \\
Q_{S H 3_{H P}}=m_{s}\left(h_{14}-h_{13}\right)_{H P}=m_{g} C_{p g}\left(T_{g 3}-T_{g 4}\right) \\
\left(Q_{E V A}\right)_{H P}=m_{s}\left(h_{12}-h_{11}\right)_{H P}=m_{g} C_{p g}\left(T_{g 4}-T_{g 5}\right) \\
\left(Q_{E C}\right)_{H P}=Q_{E C 1_{H P}}+Q_{E C 2_{H P}}+Q_{E C 3_{H P}} \\
Q_{E C 1_{H P}}=m_{w}\left(h_{10}-h_{9}\right)_{H P}=m_{g} C_{p g}\left(T_{g 5}-T_{g 6}\right) \\
Q_{E C 2_{H P}}=m_{w}\left(h_{9}-h_{8}\right)_{H P}=m_{g} C_{p g}\left(T_{g 6}-T_{g 7}\right) \\
Q_{E C 3_{H P}}=m_{w}\left(h_{8}-h_{7}\right)_{H P}=m_{g} C_{p g}\left(T_{g 7}-T_{g 8}\right) \\
\left(Q_{S H}\right)_{L P}=m_{s}\left(h_{6}-h_{5}\right)_{L P}=m_{g} C_{p g}\left(T_{g 8}-T_{g 9}\right) \\
\left(Q_{E V A}\right)_{L P}=m_{s}\left(h_{4}-h_{3}\right)_{L P}=m_{g} C_{p g}\left(T_{g 9}-T_{g 10}\right) \\
\left(Q_{E C}\right)_{L P}=m_{w}\left(h_{2}-h_{1}\right)_{L P}=m_{g} C_{p g}\left(T_{g 10}-T_{g 11}\right)
\end{gathered}
$$

The temperature of the gas leaving the high pressure evaporator

$$
T_{11}=T_{s H P}+T_{P P}
$$

where $T_{s}$; is the saturation steam temperature at high pressure level.

Also the temperature of water into evaporator is $T_{11}=T_{s H P}-T_{A P}$

\subsection{Steam Generation Calculation Model}

$$
m_{s H P}=\frac{m_{g} C_{p g}\left(T_{g 1}-T_{g 8}\right)}{\left(h_{s s}-h_{s}\right)_{H P}}
$$




$$
m_{s L P}=\frac{m_{g} C_{p g}\left(T_{g 8}-T_{g 11}\right)}{\left(h_{s s}-h_{s}\right)_{L P}}
$$

\section{Results and Discussions}

The result from the direct observation and measurement of the operating parameters of the HRSG, including data from the log book for the period under consideration are recorded in Table 1. These give detail of an average daily reading recorded from the human machine interface (HMI). The data include the feed water pressure, feed water temperature, feed water mass flow, steam pressure, steam temperature, stack temperature and steam mass flow for the low and high pressure levels, while Table 2 show the average operating data of the gas turbine plant for the period under consideration. The data measured include the ambient temperature, pressure, humidity, fuel gas flow rate, exhaust gas mass flow.

The Experiment platform was done through direct data monitoring on the human machine interface (HMI). See Appendix I for the experimental screen shot.

Hysys simulator was used to model the temperature gradient across the various heat exchanging units of the HRSG after several iterations. This gave the preliminary process of flow diagram, mass and energy balance at various gas turbine exhaust gas temperature and mass flow rate. For the normal operating mode; part load and base load, Tables 3-7 gives the heat exchange properties and performance detail.

A numerical method (MATLAB software) was also used to simulate the steam pressure, temperature, steam quality, effectiveness, and heat flux distribution for predicting the performance of the HRSG.

To calculate the performance of the heat exchangers in the HRSG in MATLAB, optimum performance was determined by sensitivity analyses of the varied parameters.

The optimum mode was modeled via sensitivity study by varying exhaust gas temperature and mass flow, steam pressure, steam flow from measurement.

Tables 3-7 show the results of the modeled equations using MATLAB program. The model gave the heat duty, log mean temperature difference, the heat transfer coefficient for the heating surfaces of the HRSG at exhaust gas temperature of $490^{\circ} \mathrm{C}, 500^{\circ} \mathrm{C}, 510^{\circ} \mathrm{C}, 520^{\circ} \mathrm{C}$, and $526^{\circ} \mathrm{C}$ respectively.

The results in Tables 3-7 were plotted as shown in Figures 1-3. The figures show the behavior of the heating elements in the HRSG. The heat duty of the element is plotted at different gas turbine exhaust gas temperature as shown in Figure 1. This give the various heat absorbed capacity of the heating surfaces of the HRSG. Figure 2 gave the heat exchange trend within the HRSG system, while Figure 3 show the plot of the total heat exchange at different exhaust gas temperature of the gas turbine.

Tables 8-11 show the results of the simulation for the exhaust gas temperature, HRSG effectiveness, steam

Table 3. HRSG performance analysis at exhaust gas temperature of $490^{\circ} \mathrm{C}$.

\begin{tabular}{cccccccc}
\hline Surface & Gas in ${ }^{\circ} \mathrm{C}$ & Gas out ${ }^{\circ} \mathrm{C}$ & $\begin{array}{c}\text { Water/Steam } \\
\text { in, }{ }^{\circ} \mathrm{C}\end{array}$ & $\begin{array}{c}\text { Water/Steam } \\
\text { out, }{ }^{\circ} \mathrm{C}\end{array}$ & $\begin{array}{c}\text { Heat Duty } \\
\text { KW }\end{array}$ & LMTD & UA KW/K \\
\hline HP SH1 & 490 & 477 & 432 & 470 & 6824 & 24.97 & 317.82 \\
HP SH2 & 477 & 461 & 400 & 432 & 8398 & 52.59 & 185.67 \\
HP SH3 & 461 & 431 & 349 & 400 & 15740 & 70.98 & 257.84 \\
HP EVA & 431 & 360 & 336 & 349 & 37270 & 47.21 & 918.05 \\
HP EC1 & 360 & 344 & 302 & 336 & 8399 & 32.17 & 303.63 \\
HP EC2 & 344 & 314 & 278 & 302 & 15750 & 38.92 & 470.52 \\
HP EC3 & 314 & 298 & 224 & 278 & 8399 & 52.71 & 185.19 \\
LP SH & 298 & 239 & 184 & 228 & 30970 & 62.2 & 578.98 \\
LP EVA & 239 & 182 & 115 & 184 & 29920 & 60.81 & 572.19 \\
LP EC & 183 & 129 & 80 & 115 & 27820 & 57.53 & 562.28 \\
\hline
\end{tabular}


Table 4. HRSG performance analysis at exhaust gas temperature of $500^{\circ} \mathrm{C}$.

\begin{tabular}{rccccccc}
\hline Surface & Gas in ${ }^{\circ} \mathrm{C}$ & Gas out ${ }^{\circ} \mathrm{C}$ & $\begin{array}{c}\text { Water/Steam } \\
\text { in, }{ }^{\circ} \mathrm{C}\end{array}$ & $\begin{array}{c}\text { Water/Steam } \\
\text { out, }{ }^{\circ} \mathrm{C}\end{array}$ & $\begin{array}{c}\text { Heat Duty } \\
\mathrm{KW}\end{array}$ & LMTD & UA KW/K \\
\hline HP SH1 & 500 & 460 & 370 & 450 & 20990 & 68.06 & 107.63 \\
HP SH2 & 460 & 436 & 356 & 370 & 12590 & 84.9 & 172.43 \\
HP SH3 & 436 & 390 & 330 & 356 & 24150 & 67.29 & 417.33 \\
HP EVA & 450 & 395 & 284 & 330 & 28350 & 49.33 & 668.31 \\
HP EC1 & 390 & 336 & 254 & 284 & 20990 & 38.77 & 509.66 \\
HP EC2 & 336 & 298 & 224 & 254 & 16790 & 41.97 & 465.19 \\
HP EC3 & 298 & 264 & 200 & 224 & 14690 & 37.97 & 449.93 \\
LP SH & 264 & 236 & 150 & 194 & 24670 & 45.88 & 625.19 \\
LP EVA & 236 & 200 & 120 & 150 & 24150 & 46.41 & 605.05 \\
LP EC & 163 & 119 & 85 & 120 & 13120 & 38.32 & 398.07 \\
\hline
\end{tabular}

Table 5. HRSG performance analysis at exhaust gas temperature of $510^{\circ} \mathrm{C}$.

\begin{tabular}{rccccccc}
\hline Surface & Gas in ${ }^{\circ} \mathrm{C}$ & Gas out ${ }^{\circ} \mathrm{C}$ & $\begin{array}{c}\text { Water/Steam } \\
\text { in, }{ }^{\circ} \mathrm{C}\end{array}$ & $\begin{array}{c}\text { Water/Steam } \\
\text { out, }{ }^{\circ} \mathrm{C}\end{array}$ & $\begin{array}{c}\text { Heat Duty } \\
\mathrm{KW}\end{array}$ & LMTD & UA KW/K \\
\hline HP SH1 & 510 & 455 & 435 & 503 & 28871 & 12.38 & 271.1 \\
HP SH2 & 455 & 439 & 406 & 435 & 8398.7 & 25.96 & 376.19 \\
HP SH3 & 439 & 414 & 358 & 406 & 13123 & 43.49 & 350.86 \\
HP EVA & 414 & 388 & 336 & 358 & 13648 & 53.98 & 294.02 \\
HP EC1 & 388 & 366 & 304 & 336 & 11548 & 56.85 & 236.18 \\
HP EC2 & 366 & 314 & 266 & 304 & 27296 & 54.71 & 580.23 \\
HP EC3 & 314 & 288 & 192 & 266 & 13648 & 69.25 & 229.17 \\
LP SH & 288 & 254 & 164 & 220 & 17847 & 78.49 & 264.41 \\
LP EVA & 254 & 170 & 136 & 164 & 44093 & 57.53 & 891.24 \\
LP EC & 170 & 120 & 90 & 132 & 26246 & 33.84 & 901.78 \\
\hline
\end{tabular}

Table 6. HRSG performance analysis at exhaust gas temperature of $520^{\circ} \mathrm{C}$.

\begin{tabular}{rccccccc}
\hline Surface & Gas in ${ }^{\circ} \mathrm{C}$ & Gas out ${ }^{\circ} \mathrm{C}$ & $\begin{array}{c}\text { Water/Steam } \\
\text { in, }{ }^{\circ} \mathrm{C}\end{array}$ & $\begin{array}{c}\text { Water/Steam } \\
\text { out, }{ }^{\circ} \mathrm{C}\end{array}$ & $\begin{array}{c}\text { Heat Duty } \\
\text { KW }\end{array}$ & LMTD & UA KW/K \\
\hline HP SH1 & 520 & 482 & 449 & 504 & 19947 & 23.48 & 987.69 \\
HP SH2 & 482 & 417 & 385 & 449 & 34120 & 32.49 & 1220.8 \\
HP SH3 & 417 & 387 & 319 & 385 & 15748 & 47.76 & 383.41 \\
HP EVA & 387 & 326 & 256 & 319 & 32020 & 69 & 539.64 \\
HP EC1 & 326 & 298 & 216 & 256 & 14698 & 75.84 & 225.35 \\
HP EC2 & 298 & 282 & 178 & 216 & 28398 & 92.57 & 105.5 \\
HP EC3 & 282 & 266 & 148 & 178 & 34199 & 44.2 & 110.48 \\
LP SH & 266 & 245 & 189 & 235 & 15223 & 42.28 & 418.71 \\
LP EVA & 245 & 180 & 118 & 189 & 34120 & 58.95 & 673.03 \\
LP EC & 180 & 131 & 70 & 118 & 25721 & 61.5 & 486.32 \\
\hline
\end{tabular}


Table 7. HRSG performance analysis at exhaust gas temperature of $526^{\circ} \mathrm{C}$.

\begin{tabular}{rccccccc}
\hline Surface & Gas in ${ }^{\circ} \mathrm{C}$ & Gas out ${ }^{\circ} \mathrm{C}$ & $\begin{array}{c}\text { Water/Steam } \\
\text { in, }{ }^{\circ} \mathrm{C}\end{array}$ & $\begin{array}{c}\text { Water/Steam } \\
\text { out, }{ }^{\circ} \mathrm{C}\end{array}$ & $\begin{array}{c}\text { Heat Duty } \\
\text { KW }\end{array}$ & LMTD & UA KW/K \\
\hline HP SH1 & 526 & 500 & 460 & 490 & 13640 & 26.88 & 590.06 \\
HP SH2 & 500 & 486 & 420 & 460 & 52489 & 51.92 & 162.35 \\
HP SH3 & 486 & 450 & 375 & 420 & 18897 & 70.41 & 312.1 \\
HP EVA & 450 & 395 & 350 & 375 & 28871 & 58.72 & 571.63 \\
HP EC1 & 395 & 340 & 294 & 330 & 28871 & 54.95 & 441.62 \\
HP EC2 & 340 & 306 & 266 & 294 & 17847 & 42.93 & 483.4 \\
HP EC3 & 306 & 285 & 189 & 266 & 11023 & 63.97 & 200.38 \\
LP SH & 285 & 250 & 180 & 240 & 18372 & 56.58 & 377.55 \\
LP EVA & 250 & 165 & 135 & 180 & 44618 & 64.87 & 799.76 \\
LP EC & 165 & 116 & 70 & 135 & 25721 & 57.98 & 515.86 \\
\hline
\end{tabular}



Figure 1. Absorbed heat distribution profile across the heating surfaces.

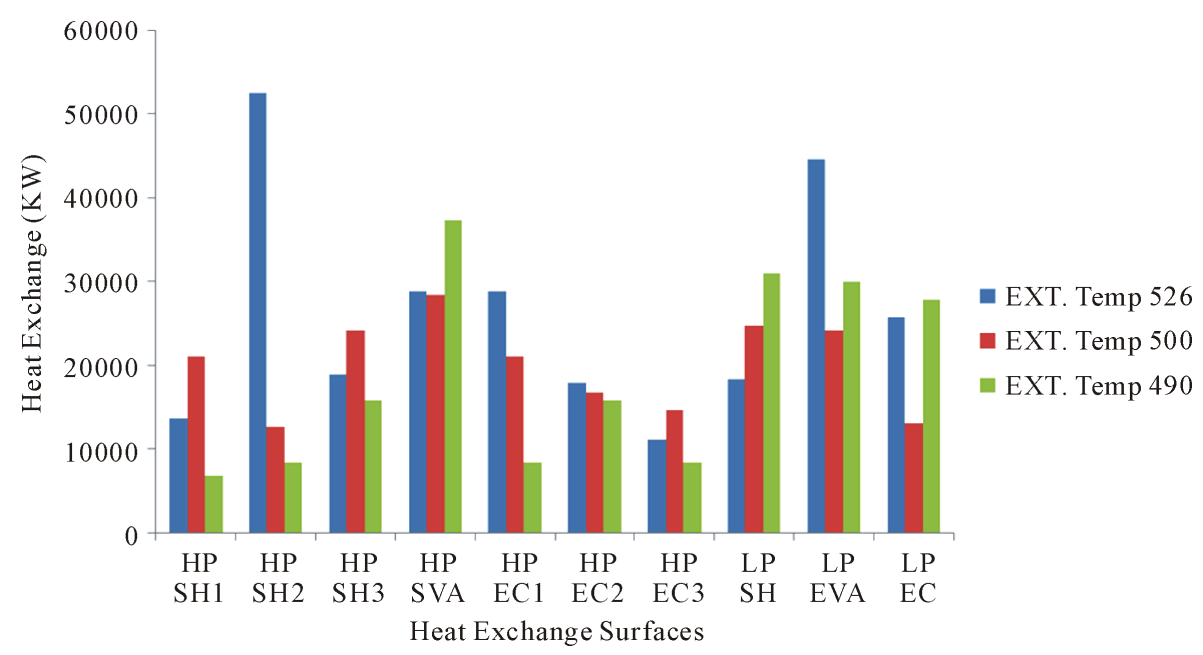

Figure 2. Absorbed heat across the heating element of the HRSG. 


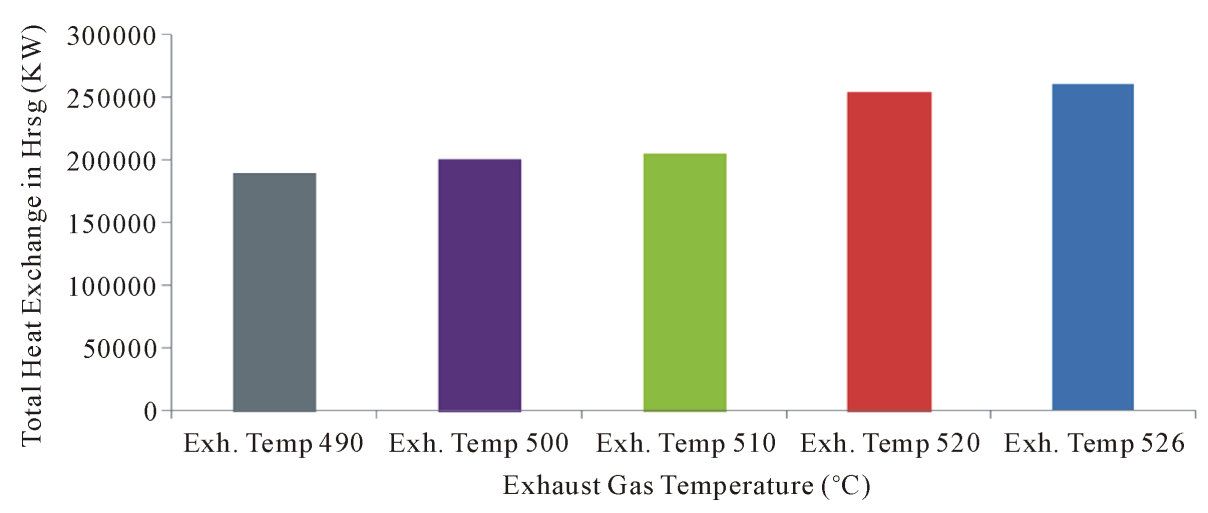

Figure 3. Total heat exchange in HRSG at different gas turbine exhaust temperature.

Table 8. Exhaust gas temp and turbine work at different pressure ratio.

\begin{tabular}{crcc}
\hline Pressure Ratio & TIT avg. ${ }^{\circ} \mathrm{C}$ & Exh. Gas Temp ${ }^{\circ} \mathrm{C}$ & Turbine Work (MW) \\
\hline 11 & 970 & 579 & 210 \\
12 & 970 & 568 & 216 \\
13 & 970 & 559 & 221 \\
14 & 970 & 550 & 225 \\
15 & 970 & 543 & 229 \\
\hline
\end{tabular}

Table 9. HRSG effectiveness at different exhaust gas temperature.

\begin{tabular}{ccccc}
\hline \multirow{2}{*}{$\begin{array}{c}\text { HRSG Heating } \\
\text { Surfaces }\end{array}$} & $526^{\circ} \mathrm{C}$ & $520^{\circ} \mathrm{C}$ & $510^{\circ} \mathrm{C}$ & $490^{\circ} \mathrm{C}$ \\
\cline { 2 - 5 } HPSH1 & 0.7135 & 0.7769 & 0.8072 & 0.9743 \\
HPSH2 & 0.6727 & 0.8877 & 0.7963 & 0.5591 \\
HPSH3 & 0.5454 & 0.9061 & 0.7973 & 0.6126 \\
HPEVA & 0.3364 & 0.647 & 0.3795 & 0.1841 \\
HPEC1 & 0.4795 & 0.4848 & 0.5725 & 0.7887 \\
HPEC2 & 0.5091 & 0.426 & 0.5113 & 0.4892 \\
HPEC3 & 0.8854 & 0.3012 & 0.8161 & 0.8072 \\
LPSH & 0.252 & 0.2635 & 0.1992 & 0.1702 \\
LPEVA & 0.1726 & 0.2465 & 0.1046 & 0.2454 \\
LPEC & 0.2091 & 0.1924 & 0.2315 & 0.1729 \\
\hline
\end{tabular}

Table 10. HRSG effectiveness at different steam pressure.

\begin{tabular}{cccc}
\hline \multicolumn{2}{c}{ Steam Pressures bar } & \multicolumn{2}{c}{ Effectiveness } \\
\hline $\mathrm{LP}\left(250^{\circ} \mathrm{C}\right)$ & $\mathrm{HP}\left(510^{\circ} \mathrm{C}\right)$ & $\mathrm{LP}$ & $\mathrm{HP}$ \\
\hline 4 & 80 & 0.5397 & 0.3763 \\
6 & 100 & 0.5389 & 0.3717 \\
8 & 120 & 0.5373 & 0.3670 \\
10 & 140 & 0.5356 & 0.3621 \\
12 & 160 & 0.5339 & 0.3571 \\
\hline
\end{tabular}


Table 11. Steam generation at different steam.

\begin{tabular}{|ccccc|}
\hline \multicolumn{4}{c}{ Pressure under constant Exh. Temp \& Flow } \\
\hline \multicolumn{2}{|c|}{ Steam Pressure, bar } & Exh. Gas Mass & \multicolumn{2}{c}{ Steam Flow, kg/s } \\
\cline { 1 - 1 } LP@256 & HP@510 & Flow & LP & HP \\
\hline 4 & 80 & 470 & 65.47 & 178.63 \\
6 & 90 & 470 & 65.67 & 180.92 \\
8 & 100 & 470 & 65.88 & 184.31 \\
10 & 110 & 470 & 66.09 & 187.34 \\
12 & 120 & 470 & 66.31 & 190.54 \\
\hline
\end{tabular}

generation analysis. The simulations were done by varying the parameters at various operating conditions. The modeled functions were the effectiveness at different steam pressure, effectiveness at different exhaust gas temperature, steam generation at different, exhaust gas flow and different steam pressure.

Figure 1, Figure 2 and Tables 3-7 show the absorbing capacity of the various heating element of the HRSG. The results give the amount of heat exchange in the superheater, economizer, and evaporator in both the low pressure and high pressure sections respectively. The plots show that HPSH2 had the highest heat exchange when the gas turbine exhaust gas temperature is $526^{\circ} \mathrm{C}$. At the exhaust gas temperature of $500^{\circ} \mathrm{C}$, the HPEVA had the highest heat exchange. The HPEVA give the same result when the exhaust gas temperature was at $520^{\circ} \mathrm{C}$ and $490^{\circ} \mathrm{C}$ reflectively. While when the exhaust gas temperature was $510^{\circ} \mathrm{C}$, the highest heat exchange occurred in the LPEVA.

From Figure 3, the amount of heat absorbed increased as the exhaust gas increased. This shows that the temperature gradient of the exhaust gas of the gas turbine imparted greatly on the energy efficiency of the HRSG. The result shows that between $490^{\circ} \mathrm{C}$ and $526^{\circ} \mathrm{C}$, the temperature difference was $36^{\circ} \mathrm{C}$ and there is a percentage increase in the heat absorbed of about $37.39 \%$. This represents an increase in heat absorption of $1.04 \%$ for every $1^{\circ} \mathrm{C}$ increase in the gas turbine exhaust gas temperature at constant flow.

Table 11 and Figure 4, Figure 5, showed the steam generated by varying the steam pressure at constant steam temperature and exhaust gas mass flow for the LP and HP sections. The LP steam pressure variation was carried out at $256^{\circ} \mathrm{C}$ and $470 \mathrm{~kg} / \mathrm{s}$, while the HP was done at $510^{\circ} \mathrm{C}$ and $470 \mathrm{~kg} / \mathrm{s}$. The result show that as the steam pressure increased from 4 bar to 12 bar for the LP and 80 bar to 120 bar for the HP, there exist a percentage increase in the steam generation of about $0.21 \%$ and $0.07 \%$ for the LP and HP respectively. This analysis represent that for every $1^{\circ} \mathrm{C}$ increase in the steam pressure under the various consideration, the steam generation increased by $0.11 \%$ and $0.30 \%$ for the LP and HP section respectively.

It also shows the effectiveness of the HRSG LP and HP at different steam generation. The result indicated that for every $40 \mathrm{~kg} / \mathrm{s}$ increase in the steam flow, the system effectiveness improved by about $13.3 \%$ in the LP section. The HP section shows that as the steam flow increased by $110 \mathrm{~kg} / \mathrm{s}$, the effectiveness of the system improved by $0.18 \%$. The research indicated that the system effectiveness for the low pressure and high pressure level at different steam pressure. The result shows that as the steam pressure increased by 1 bar, the effectiveness of the system decrease slightly by about $0.073 \%$.

Table 9 and Figure 6 showed the effectiveness of the heating surface at different gas turbine exhaust gas temperatures. It indicates that at $526^{\circ} \mathrm{C}$, the $\mathrm{HPSH} 1$ show the highest effectiveness in heat exchange. At $520^{\circ} \mathrm{C}$, HPSH3 effectiveness was about $91 \%$, while at $510^{\circ} \mathrm{C}$ and $490^{\circ} \mathrm{C}$, $\mathrm{HPSH} 1$ gave about $80 \%$ and $97 \%$ respectively. This represents that the heat exchange efficiency could be optimum at higher exhaust gas temperature and higher mass flow.

The results of the analysis were compared with the work of Mohammad et al. [12] and its show a similar trend in the temperature profile for both the gas-side and the water/steam side. Although Mohammad et al. [12] did not analysed the effectiveness of the heating surfaces and steam flow. Further comparison of simulated result was made with the work of Vytla [20], where fluent was used to analysed the HRSG performance with 21 heating surfaces (heat Exchangers). The temperature profile of the gas-side of this work follows the trend with minimal variation. 


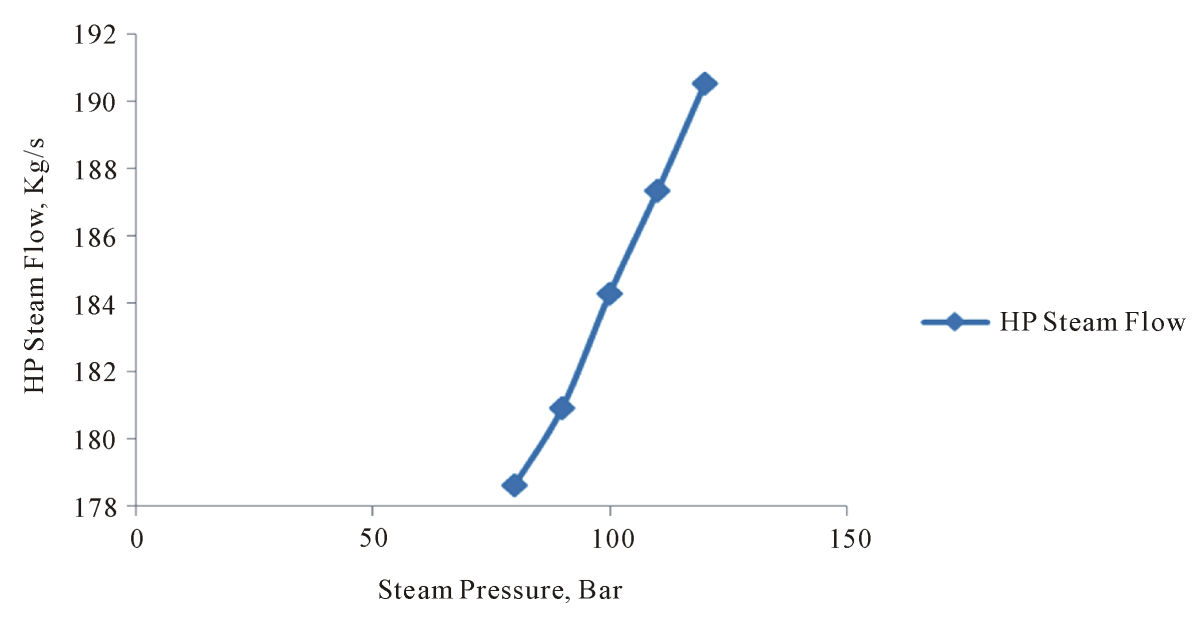

Figure 4. HP Steam generation at different steam pressure at constant exhaust gas flow.

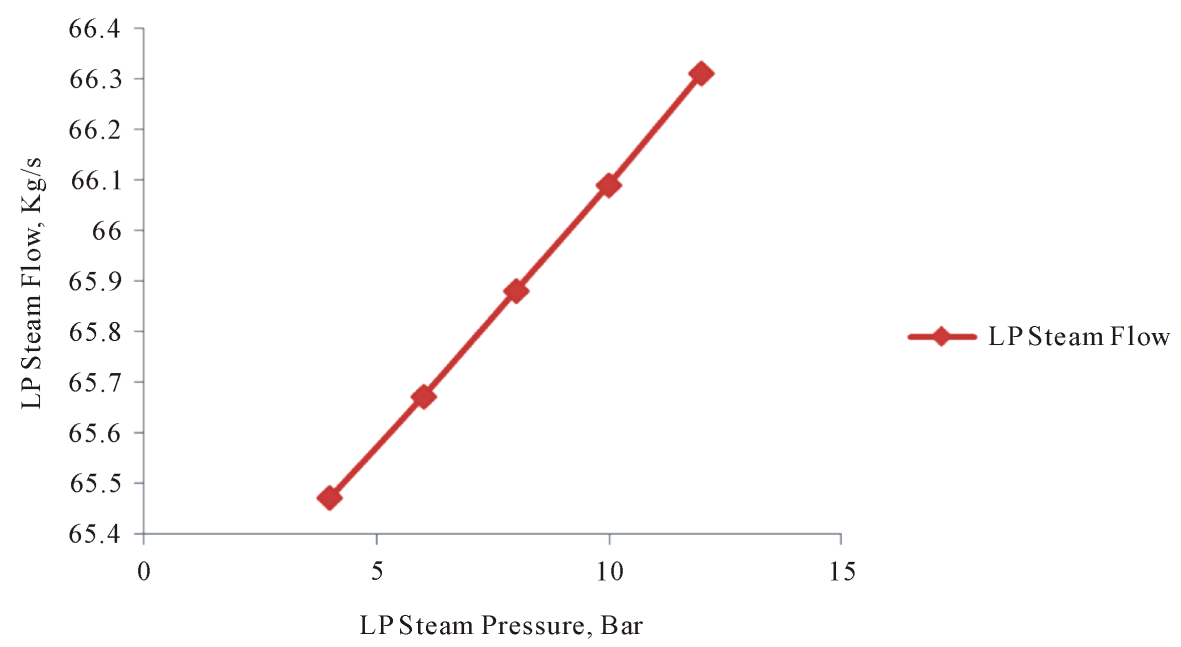

Figure 5. LP Steam generation at different steam pressure at constant exhaust gas flow.

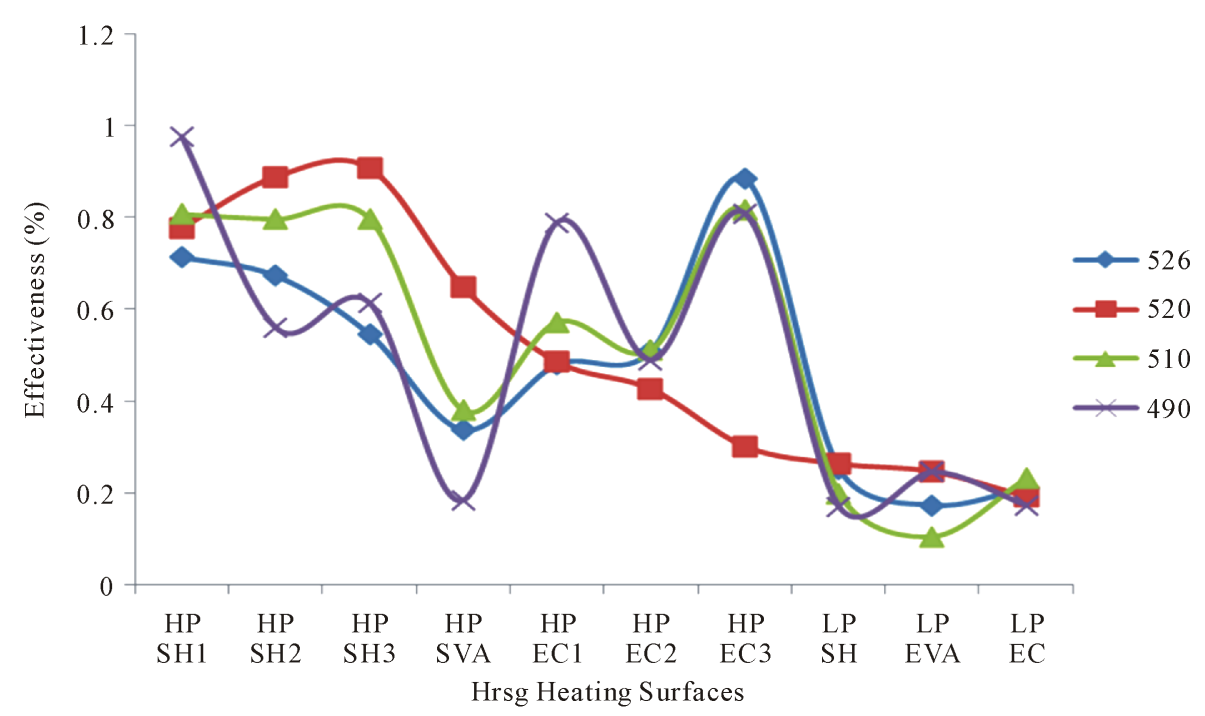

Figure 6. Effectiveness of the heating surfaces of the HRSG at different exhaust temperatures. 


\section{Conclusions}

The work revealed the various parameters and energy based equations used in assessing the heat duty and effectiveness of the HRSG at various operating condition of the gas turbine exhaust in order to sustain its performance.

The sensitivity study carried out by varying the operating parameters, such as mass flow, steam pressure, exhaust gas temperature was analysed and the impact on the HRSG performance evaluated. The results for both the optimum mode and normal mode were compared. It provides a good improvement in the performance, especially in steam generation and heat exchange capacity. With this analysis, a predictive temperature distribution profile across the heating surfaces of the HRSG was established.

\section{References}

[1] Casarosa, F., Donatin, C. and Franco, A. (2004) Thermoeconomic Optimization of Heat Recovery Steam Generator Operating Parameters for Combined Plant. Energy, 29, 389-413. http://dx.doi.org/10.1016/S0360-5442(02)00078-6

[2] Lebele-Alawa, B.T., Hart, H.T., Ogaji, S.O.T. and Probert, S.D. (2008) Rotor-Blades’ Profile Influence on a Gas Turbine's Compressor Effectiveness. Applied Energy, 85, 494-505. http://dx.doi.org/10.1016/j.apenergy.2007.12.001

[3] Lebele-Alawa, B.T. (2010) Axial Thrust Responses due to a Gas Turbine’s Rotor Blade Distortions Journal of Engineering Physics and Thermophysics, 83, 991-994. http://dx.doi.org/10.1007/s10891-010-0423-2

[4] Lebele-Alawa, B.T. and Egwanwo, V. (2012) Numerical Analysis of the Heat Transfer in Heat Exchangers. International Journal of Applied Science and Technology, 2, 60-64.

[5] Ganapathy, V. (2001) Optimize Energy Efficiency of the Heat Recovery Steam Generator. Power Engineering Article, 105. http://www.power-eng.com/articles/print/volume-

[6] Ongiro, A., Ugursal, V.I., Al Taweel, A.M. and Walker, J.D. (1997) Modeling of Heat Recovery Steam Generator Performance. Applied Thermal Engineering, 16, 427-444. http://dx.doi.org/10.1016/S1359-4311(96)00052-X

[7] Franco, A. and Russo, A. (2002) Combined Cycle Plant Efficiency Increase Based on the Optimization of Heat Recovery Steam Generator Operating Parameter. International Journal of Thermal Science, 41, 841-850. http://dx.doi.org/10.1016/s1290-0729(02)01378-9

[8] Reddy, B.V., Ramkiran, G., Kumar, K.A. and Nag, P.K. (2002) Second Law Analysis of a Waste Heat Recovery Steam Generator. International Journal of Heat and Mass Transfer, 45, 1807-1814. http://dx.doi.org/10.1016/S0017-9310(01)00293-9

[9] Subhramanyam, N., Rajaram, S. and Kamalnathan, N. (1995) HRSGs for Combined Cycle Power plants. Heat Recovery System \& CHP, 15, 153-161. http://dx.doi.org/10.1016/0890-4332(95)90022-5

[10] Dumont, M.N. and Heyen, G. (2004) Mathematical Modeling and Design of an Advanced Once through Heat Recovery Steam Generator. Computers and Chemical Engineering, 28, 651-660. http://dx.doi.org/10.1016/j.compchemeng.2004.02.034

[11] Valdés, M., Durán, M.D. and Rovira, A. (2003) Thermoeconomic Optimist of Combined Cycle Gas Trubine Power Plants Using Genetic Algorithms. Applied Thermal Engineering, 23, 2168-2180. http://dx.doi.org/10.1016/S1359-4311(03)00203-5

[12] Mohammad, T.M., Pouria, A., Abdolsaeid, G.K. and Mohammad, N.M.J. (2012) Exergetic and Economic Evaluation of the Effect of HRSG Configurations on the Performance of Combined Cycle Power Plants. Journal of Energy Conversion and Management, 58, 47-58.

[13] Attala, L., Facchini, B. and Ferrara, B. (2001) Thermo Economic Optimization Method as Design Tool in Gas Steam Combined Plant Realisation. Energy Conversation and Management, 42, 2163-2172. http://dx.doi.org/10.1016/S0196-8904(00)00129-1

[14] Bassily, A.M. (2007) Analysis and Cost Optimization of the Triple-Pressure Steam-Reheat Gas Reheat Gas-Recuperated Combined Power Cycle. International Journal of Energy Research, 32, 116-135. http://dx.doi.org/10.1002/er.1338

[15] Srinivas, T. (2009) Study of a Deaerator Location in Triple Pressure-Reheat Combined Power Cycle. Energy, 34, 1364-1371. http://dx.doi.org/10.1016/j.energy.2009.05.034

[16] Mohagheghi, M. and Shayegan, J. (2009) Thermodynamic Optimization of Design Variable and Heat Exchanger Layout in HRSGs for CCGT, Using Genetic Algorithm. Applied Thermal Engineering, 29, 290-298. http://dx.doi.org/10.1016/j.applthermaleng.2008.02.035

[17] Sun, Z.X., Gao, L., Wang, J.F. and Dai, Y.P. (2012) Dynamic Optimal Design of Power Generation System Utilizing Industrial Waste Heat Considering Parameter Fluctuations of Exhaust Gas. Energy, 44, 1035-1043. 
http://dx.doi.org/10.1016/j.energy.2012.04.043

[18] Manassaldi, J.I. and Scenna, N.J. (2011) Optimal Synthesis and Design of Heat Recovery Steam Generation (HRSG) via Mathematical Programming. Energy, 36, 475-485. http://dx.doi.org/10.1016/j.energy.2010.10.017

[19] Alus, M.M. and Petrovic, M.V. (2012) Optimization of Parameters for Heat Recovery Steam Generator (HRSG) in Combined Cycle Plants. Thermal Science, 16, 901-914. http://dx.doi.org/10.2298/TSCI120517137A

[20] Ghazi, M., Ahmadi, P., Stotoodeh, A.F. and Taherkhani, A. (2012) Modeling and Thermo-Economic Optimization of Heat Recovery Heat Exchanger Using a Multimodal Genetic Algorithm. Energy Conservation and Management, 58, 149-156. http://dx.doi.org/10.1016/j.enconman.2012.01.008

[21] Vytla, V.V.S.K. (2005) Thesis on CFD Modeling of Heat Recovery Steam Generator and Its Components Using Fluent. College of Engineering, University of Kentucky, Lexington.

[22] Lebele-Alawa, B.T. and Asuo, J.M. (2011) Exergy Analysis of Kolo Creek Gas Turbine Plant. Canadian Journal of Mechanical Science and Engineering, 2, 172-184.

[23] Lebele-Alawa, B.T. and Jo-Appah, V. (2015) Thermodynamic Performance Analysis of a Gas Turbine in an Equatorial Rain Forest Environment. Journal of Power and Energy Engineering, 3, 11-23. http://dx.doi.org/10.4236/jpee.2015.31002

[24] Ahmadi, P., Hajadollahi, H. and Dincer, I. (2011) An Exergy-Based Multi-Objective Optimization of a Heat Recovery Steam Generator (HRSG) in a Combined Cycle Power Plant (CCPP) Using Evolutionary Algorithm. International Journal of Green Energy, 8, 44-64. http://dx.doi.org/10.1080/15435075.2010.529779

[25] Ahmadi, P. and Dincer, I. (2011) Thermodynamic Analysis and Thermoeconomic Optimization of a Dual Pressure Combined Cycle Power Plant with a Supplementary Firing Unit. Energy Convers Manage, 52, 296-308. http://dx.doi.org/10.1016/j.enconman.2010.12.023 


\section{Nomenclature}

$Q_{S H L P}$

$Q_{\text {EVALP }}$

$Q_{E C L P}$

$Q_{a v}$

$Q_{d b}$

$Q_{\max }$

$T_{g 1-11}$

$T_{P P}$

$T_{A P}$

$T_{S}$

$T_{3}$

$T_{4}$

$T_{\text {gin }}$

$T_{\text {gout }}$

$T_{\text {win }}$

$T_{\text {wout }}$

$U$

$\varepsilon_{H R S G L P}$

$\varepsilon_{\text {HRSGHP }}$

$\eta_{G T}$

$A_{T}$

$C_{p g}$

$C_{p s}$

$C_{p w}$

$f$

$h_{1-11}$

$h_{s s}$

$h_{s}$

LHV

LMTD

$m_{g}$

$m_{w}$

$m_{\text {sHP }}$

$m_{\text {SLP }}$

$Q_{(S H 1-3) H P}$

$Q_{\text {EVAHP }}$

$Q_{(E C 1-3) H P}$

S.H

MCR
Heat Duty of the Superheater Low Pressure Section

$\mathrm{kW}$

Heat Duty of the Evaporator in Low Pressure Section

$\mathrm{kW}$

Heat Duty of the Economizer in Low Pressure Section

$\mathrm{kW}$

$\mathrm{kW}$

$\mathrm{kW}$

Heat Rate of the Duct Burner

$\mathrm{kW}$

Maximum Possible Heat Transfer Rate

Exhaust Gas Temperature across the Heating Surfaces

Pinch Point

Approach Point

Saturation Temperature

Turbine Inlet Temperature

Exhaust Gas Temperature

Exhaust Gas Temperature into the Heating Surface

Exhaust Gas Temperature out of the Heating Surface

Feed Water/Steam Temperature into the Heating Surface

Feed Water/Steam Temperature out of the Heating Surface

Overall Heat Transfer Coefficient

Effectiveness of the components in the HRSG Low Pressure Section

Effectiveness of the components in the HRSG High Pressure Section

Turbine Isentropic Efficiency

Total Heat Transfer Area

Specific Heat Capacity of Exhaust Gas

Specific Heat Capacity of Steam

Specific Heat Capacity of Water

Correction Factor

Enthalpy of Steam across the HRSG

${ }^{\circ} \mathrm{C}$

${ }^{\circ} \mathrm{C}$

${ }^{\circ} \mathrm{C}$

${ }^{\circ} \mathrm{C}$

${ }^{\circ} \mathrm{C}$

${ }^{\circ} \mathrm{C}$

${ }^{\circ} \mathrm{C}$

${ }^{\circ} \mathrm{C}$

${ }^{\circ} \mathrm{C}$

${ }^{\circ} \mathrm{C}$

$\mathrm{kW} / \mathrm{m}^{2}$

Enthalpy of Superheated Steam

Enthalpy of Saturated Steam

Lower Heating Value of Fuel

Log Mean Temperature Difference

Exhaust Gas Mass Flow

Feed Water Mass Flow

Steam Flow in HP section

Steam Flow in LP Section

Heat Duty across the Superheaters In High Pressure Section

$\%$

$\mathrm{m}^{2}$

$\mathrm{kJ} / \mathrm{kgK}$

$\mathrm{kJ} / \mathrm{kgK}$

$\mathrm{kJ} / \mathrm{kgK}$

$\mathrm{kJ} / \mathrm{kg}$

$\mathrm{kJ} / \mathrm{kg}$

$\mathrm{kJ} / \mathrm{kg}$

$\mathrm{kJ} / \mathrm{kg}$

$\mathrm{kg} / \mathrm{s}$

$\mathrm{kg} / \mathrm{s}$

$\mathrm{kg} / \mathrm{s}$

$\mathrm{kg} / \mathrm{s}$

$\mathrm{kW}$

$\mathrm{kW}$

$\mathrm{kW}$

Heat Duty of the Economizers in High Pressure Section

$\mathrm{kg} / \mathrm{s}$ 


\section{Appendix I}

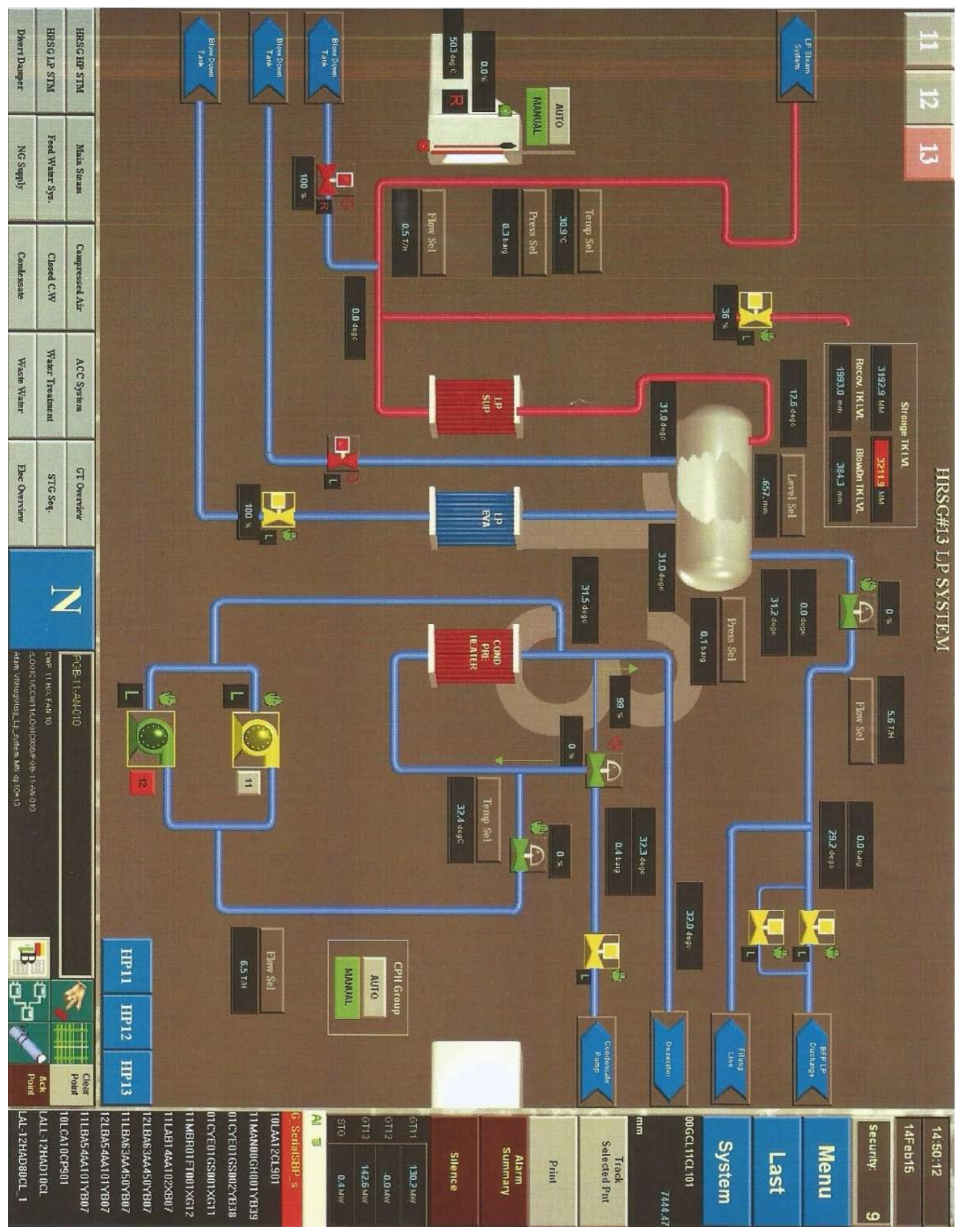









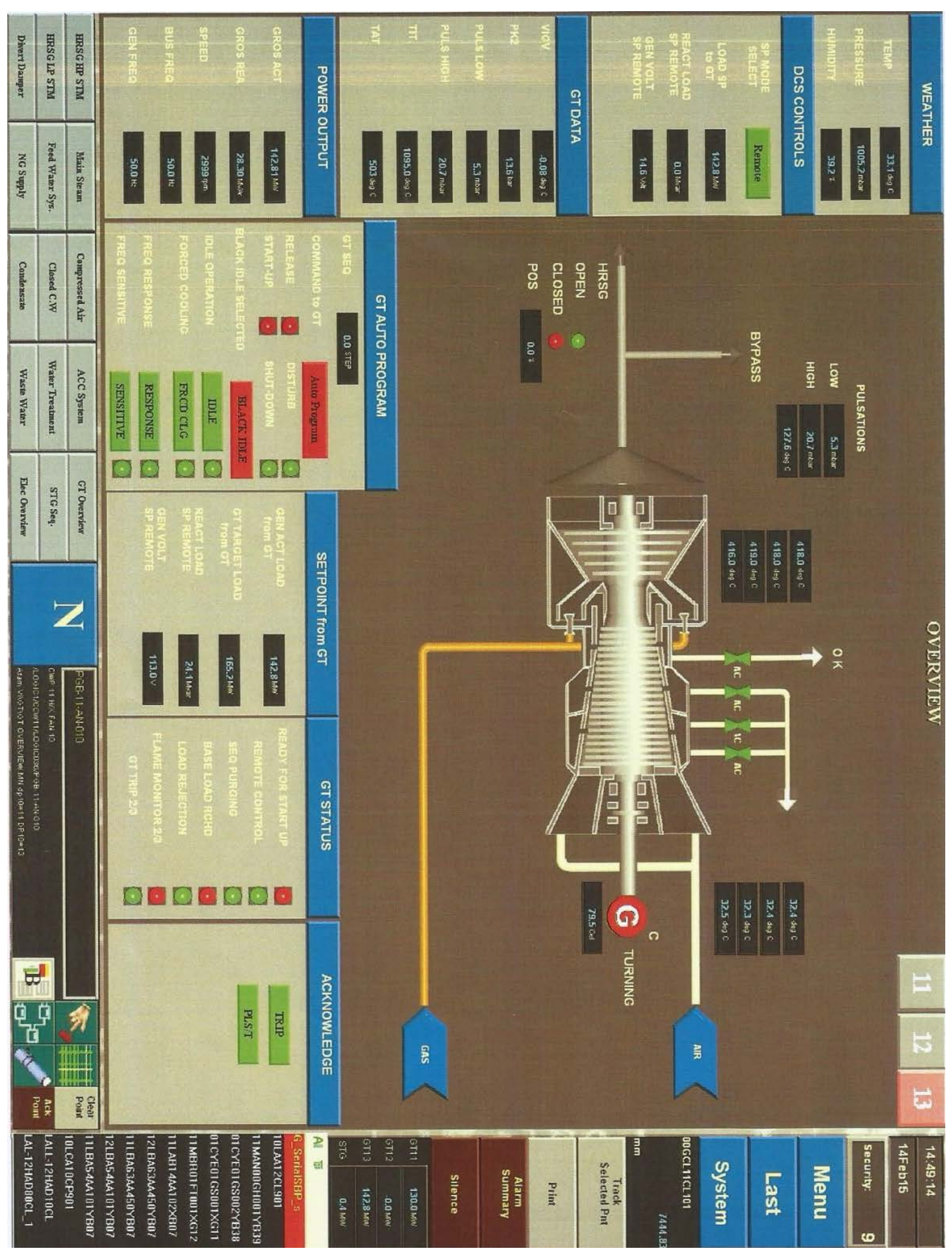

